\title{
Anti-Allergic Properties of a Matured Fruit Extract of the Date Palm Tree (Phoenix dactylifera L.) in Mite-Sensitized Mice
}

\author{
Koji KARASAWA ${ }^{1,2}$ and Hajime OTANI ${ }^{1, *}$ \\ ${ }^{1}$ Interdisciplinary Graduate School of Science and Technology, Shinshu University, \\ Minamiminowa-mura 8304, Kamiina-gun, Nagano 399-4598, Japan \\ ${ }^{2}$ Ina Food Industry Co., Ltd., Nishiharuchika 5074, Ina, Nagano 399-4498, Japan \\ (Received February 16, 2012)
}

\begin{abstract}
Summary The effects of oral ingestion of a hot water extract of matured fruit of the date palm tree (Phoenix dactylifera L.) on allergic responses were investigated in mite-sensitized mice. Sneezing and nose rubbing events in mice given a date extract-added diet were significantly lower than in those given an extract-free (control) diet. The serum total and mite antigen-specific immunoglobulin (Ig) E levels, and the number of spleen interleukin- $4^{+} \mathrm{CD} 4^{+}$, $\mathrm{IgE}^{+} \mathrm{B} 220^{+}$and $\mathrm{Fc} \varepsilon \mathrm{RI} \alpha^{+} \mathrm{CD} 117^{+}$cells was significantly lower in mice given the date extractadded diet than in those given the control diet. Chlorogenic acid, pelargonin and ferulic acid significantly reduced the number of $\mathrm{IgE}^{+} \mathrm{B} 22 \mathrm{O}^{+}$cells, while chlorogenic acid and pelargonin significantly decreased the number of $\mathrm{Fc} \varepsilon \mathrm{RI} \alpha^{+} \mathrm{CD} 117^{+}$cells in mouse spleen cell cultures. These results suggest that some polyphenols in the date may reduce mite-induced allergic symptoms in mice via a decrease in the number of IgE-producing plasma cells and highaffinity IgE receptor-expressing mast cells.
\end{abstract}

Key Words anti-allergic property, date polyphenol, Th1/Th2 balance, IgE-producing plasma cell, mast cell

Type I allergy is caused by an inappropriate reaction against food and environmental allergens. The prevalence and severity of allergic diseases such as atopic dermatitis, allergic asthma and allergic rhinitis have increased dramatically during the past decade around the world, especially in developed countries. The allergies characterized by these symptoms are generally caused by degranulation that occurs following antigen cross-linking of immunoglobulin (Ig) E molecules on mast cells (1). Thus, IgE is essential for type I allergic reactions. It is established that interleukin (IL)-4, IL-5, and IL-13, which are produced by type 2 helper T (Th2) cells, stimulate IgE production (1). In particular, IL-4 is known to play a crucial role in IgE synthesis (2). In contrast, type 1 helper $\mathrm{T}$ (Th1) cells mainly secrete interferon (IFN)- $\gamma$, which inhibits IL-4 production by the Th2 cells $(3,4)$. As a result, a strict balance between Th1 and Th2 activity is essential for the control of IgE production.

It has been demonstrated in recent years that some fruit extracts reduce allergic symptoms. Kim et al. reported that a water-soluble extract prepared from Actinidia arguta improved asthmatic symptoms via the down-regulation of IgE in mouse (5). Lee et al. found that resveratrol, which has been identified in various fruit and vegetable extracts, inhibited Th2-type cytokines such as IL-4 and IL-5, and suppressed airway

*To whom correspondence should be addressed at: Graduate School of Agriculture, Shinshu University, Minamiminowamura 8304, Kamiina-gun, Nagano 399-4598, Japan.

E-mail: otani84@shinshu-u.ac.jp hyperresponsiveness, eosinophilia, and mucus hypersecretion in an asthmatic mouse model (6).

More recently, our group observed that the ratio of Th1/Th2 cells in the spleen and Peyer's patch was higher in $\mathrm{C} 3 \mathrm{H} / \mathrm{HeN}$ mice given a diet containing a hot water extract of the matured fruit of the date palm tree (Phoenix dactylifera L.) than in mice given an extract-free diet (7), due to an increase in the number of spleen and Peyer's patch Th1 cells and a tendency for the number of Th2 cells to decrease. These results suggested that a date extract might have a suppressive effect on allergic immune responses via the adjustment of Th1/Th2 balance.

This study therefore evaluated the effect of a date extract on the allergic responses induced by a mite (Dermatophagoides farinae, Df) allergen in $\mathrm{BALB} / \mathrm{c}$ mice, and determined whether date polyphenols affect allergyassociated effector cells in $\mathrm{C} 3 \mathrm{H} / \mathrm{HeN}$ mouse spleen cell cultures.

\section{MATERIALS AND METHODS}

Materials. Phycoerythrin (PE)-labeled anti-mouse IL-4 monoclonal antibody (mAb, clone 11B11), PElabeled anti-mouse IFN- $\gamma \mathrm{mAb}$ (clone XMG1.2), PElabeled anti-mouse CD80 mAb (clone 16-10A1), biotin-labeled anti-mouse CD4 mAb (clone RM4-5), biotin-labeled anti-mouse CD45R/B220 (B220) mAb (clone RA3-6B2), biotin-labeled anti-mouse CD117 $\mathrm{mAb}$ (clone 2B8), biotin-labeled anti-mouse $\mathrm{CD} 11 \mathrm{~b}$ $\mathrm{mAb}$ (clone M1/70) and phycoerythrin/cyanine 5 (PE/ Cy5)-labeled streptavidin were purchased from BioLegend (San Diego, CA, USA). Anti-mouse FceRI $\alpha$ (clone 


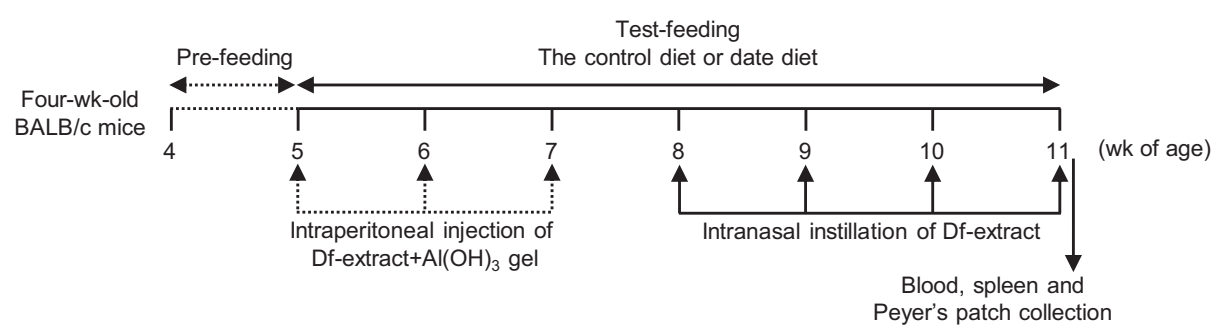

Fig. 1. Experimental schedules. After pre-breeding for a week, BALB/c mice were given the control diet or date diet between 5 and 11 wk of age. The mice were intraperitoneally injected with $200 \mu \mathrm{L}$ saline solution containing $100 \mu \mathrm{g}$ Df-extract and $2 \mathrm{mg}$ aluminum hydroxide gel at 5, 6 and $7 \mathrm{wk}$ of age, and intranasally challenged by instillation with $20 \mu \mathrm{L}$ distilled water containing $20 \mu \mathrm{g}$ Df-extract between 8 and 11 wk of age. Blood, spleen and Peyer's patch samples were collected at 11 wk of age.

G-14) and PE-labeled anti-goat IgG were obtained from Santa Cruz Biotechnology (Santa Cruz, CA, USA). Brefeldin A (BFA), ionomycin, streptomycin and phorbol 12-myristate 13-acetate (PMA) were purchased from Wako Pure Chemical Industries, Ltd. (Osaka, Japan). Dfextract, a mite allergen, was obtained from LSL (Tokyo, Japan). IntraPrep was purchased from Beckman Coulter (Marseille, France). Defined fetal bovine serum (FBS) was obtained from HyClone Laboratories (Logan, UT, USA). Penicillin was purchased from MP Biomedicals (Costa Mesa, CA, USA). Roswell Park Memorial Institute (RPMI)-1640 was purchased from Nissui Pharmaceutical (Tokyo, Japan). Horseradish peroxidase (HRP)-labeled anti-mouse IgE was obtained from Bethyl Laboratories (Montgomery, TX, USA). 3,3',5,5'-Tetramethyl benzidine (TMB) was purchased from KPL (Gaithersburg, MD, USA). Bovine serum albumin (BSA) and aluminum hydroxide gel were obtained from Sigma-Aldrich (St. Louis, MO, USA). Protocatechuic acid, chlorogenic acid, caffeic acid, pelargonin, and ferulic acid were obtained from Funakoshi Co., Ltd. (Tokyo, Japan) and syringic acid was purchased from Wako Pure Chemical Industries, Ltd. All chemicals used in this study were of the highest analytical grade commercially available.

Preparation of a date extract. Dried date fruit that was harvested in the United Arab Emirates (UAE) was obtained from Marubeni Corporation (Tokyo, Japan). The fruit $(1,000 \mathrm{~g})$, including peel and pulp but not seeds, was cut into pieces of approximate $5 \times 5 \mathrm{~mm}$, and boiled in 9,000 $\mathrm{mL}$ of hot distilled water for $2 \mathrm{~h}$ under reflux. The supernatant was collected by centrifugation $(5,000 \times g, 30 \mathrm{~min})$ and ultrafiltrated using a Stirred Ultrafiltration Unit (Model UHP-150K; Advantec Toyo Kaisha, Ltd., Tokyo, Japan) with a Molecular/Por Ultrafiltration Membrane MWCO 500 (Spectrum Laboratories, Inc., Rancho Dominguez, CA, USA) to eliminate fructose and sucrose in the extract. The residue on the membrane was then dissolved in $500 \mathrm{~mL}$ of distilled water, freeze-dried and used as the date extract. The weight of date extract obtained from 1,000 g fruit was $70 \mathrm{~g}$. The total content of polyphenols in the extract, determined according to the Folin-Ciocalteu method used by Al-Farsi et al. (8), was $32.07 \mathrm{mg}$ of ferulic acid equivalents (FAE)/g. Hence, it was calculated that $1 \mathrm{~g}$ of the date fruit contained $2.24 \mathrm{mg}$ of FAE of polyphenols.
Al-Farsi et al. reported that the content of polyphenols in the date fruit was 2.17 to $3.43 \mathrm{mg}$ of FAE/g (8). The polyphenol content of date fruit used in this study was within the amount of their report. On the other hand, we estimated that the content of protocatechuic acid, chlorogenic acid, caffeic acid, syringic acid, pelargonin and ferulic acid identified in the previous study (7) was $10.78,0.88,0.74,7.55,3.64$ and $3.15 \mathrm{mg} / \mathrm{g}$ date extract, respectively, by ultra performance liquid chromatography analysis.

Feeding procedure. Four-week-old male BALB/c mice were obtained from Japan SLC, Inc. (Shizuoka, Japan). The mice were assigned to different test regimens as shown in Fig. 1. The mice were given a commercial mouse powder feed (MF, Oriental Yeast Co., Ltd., Tokyo, Japan) for $1 \mathrm{wk}$, and were then given the defined proteinfree purified diet P5765 (Purina Mills, St. Louis, MO, USA) supplemented with $25 \%$ ovalbumin (control diet) or a mixture of $24 \%$ ovalbumin and $1 \%$ date extract (date diet) between 5 and $11 \mathrm{wk}$ of age $(n=5)$. The mice were intraperitoneally injected with $200 \mu \mathrm{L}$ saline solution containing $100 \mu \mathrm{g}$ Df-extract and $2 \mathrm{mg}$ aluminum hydroxide gel at 5, 6 and $7 \mathrm{wk}$ of age. The mice were intranasally challenged by instillation with $20 \mu \mathrm{L}$ distilled water containing $20 \mu \mathrm{g}$ Df-extract per week between 8 and 11 wk of age. The number of sneezing and nose rubbing events was then counted for $30 \mathrm{~min}$, starting 1 min after the intranasal instillation. Food and water were supplied ad libitum throughout the course of the experiment. The mice were housed at a temperature of $23 \pm 2^{\circ} \mathrm{C}$ under a standard 12-h light-dark cycle. Blood, spleen and Peyer's patch samples were collected immediately following a lethal dose of ether at $11 \mathrm{wk}$ of age. Serum was obtained by centrifugation at $450 \times g$ for $60 \mathrm{~min}$ at $4^{\circ} \mathrm{C}$ and was stored at $-30^{\circ} \mathrm{C}$ until use. All animal experimentations undertaken during this study were conducted in accordance with the guidelines for the Regulation of Animal Experimentation at Shinshu University, and according to Law no. 105 and Notification no. 6 of the Japanese government.

Spleen and Peyer's patch cell suspensions and cell cultures. Spleen and Peyer's patch cell suspensions were prepared as described previously (9). One thousand microliters of the cell suspensions were plated into the wells of a 24-well flat-bottom plate (Sarstedt, Inc., Newton, NC, 

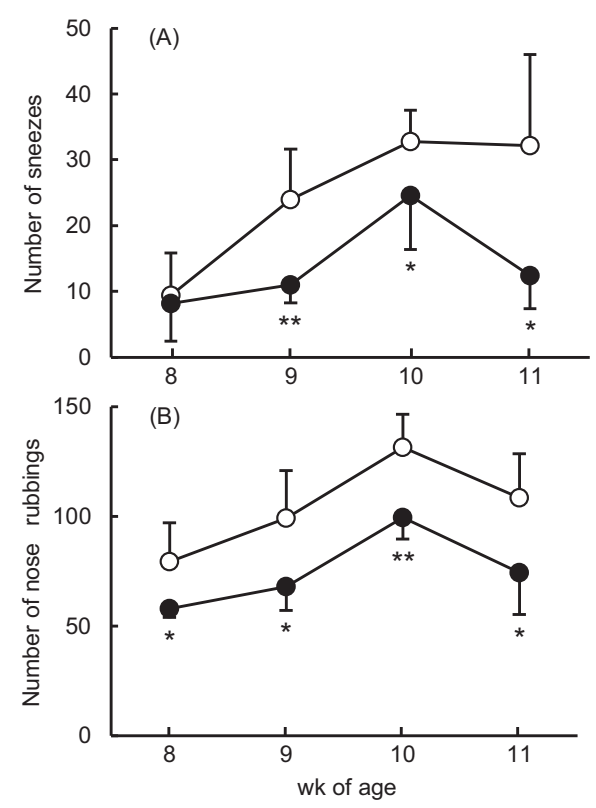

Fig. 2. The number of sneezes (A) and nose rubbings (B) in BALB/c mice given the control diet (the blank circles) or date diet (the filled circles). Sneezing and nose rubbing events were counted for $30 \mathrm{~min}$, starting 1 min after the intranasal instillation with Df-extract. Repeated measures ANOVA examining the numbers of sneezing and nose rubbing events among each group showed significant differences. Two-way ANOVA was used to analyze those between the mice given the date diet and the mice given the control diet at the same weeks of age. Data are presented as the mean \pm SD $(n=5){ }^{*} p<0.05,{ }^{* *} p<0.01$.

USA). Individual standard polyphenols were dissolved in dimethyl sulfoxide (DMSO) and added into the medium at a final concentration of $4 \mathrm{nmol} / \mathrm{mL}$. The final concentration of DMSO was $0.01 \%$, which has been determined to be noncytotoxic. The cells were cultured at $37^{\circ} \mathrm{C}$ in a humidified $5 \% \mathrm{CO}_{2}$ incubator for $48 \mathrm{~h}$ for cell function analysis.

Cell function analysis. Cell surface markers and intracellular cytokines were labeled according to a previously described procedure (10). The cell number was determined using a Guava personal cell functional analyzer (Guava PCA, Guava Technologies, Hayward, CA, USA).

Antibody analysis. Serum total and Df-specific IgE levels were measured by an enzyme-linked immunosorbent assay (ELISA) according to a previously described procedure (9).

Statistical analysis. Data are expressed as the mean \pm standard deviation (SD). Statistical analyses were performed using a statistical software package (ystat2004. xls, Igakutosho Shuppan, Tokyo, Japan). Repeated measures analysis of variance (ANOVA) was used to determine if there were significant differences in the numbers of sneezing and nose rubbing events among each group over time. When significant differences over time were detected, two-way ANOVA (diet and week as independent variables) was used to analyze the numbers of sneezing and nose rubbing events between the mice
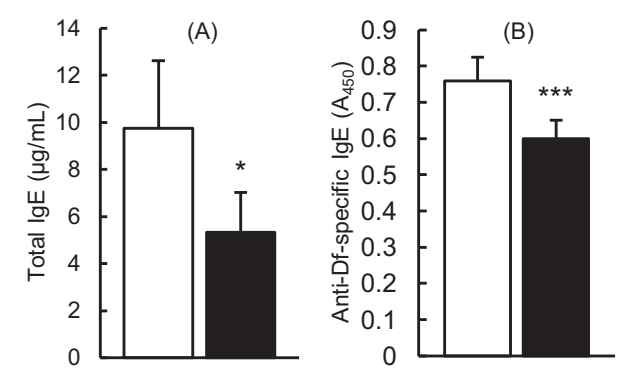

Fig. 3. Serum level of total (A) and Df-specific (B) IgE in $\mathrm{BALB} / \mathrm{c}$ mice given the control diet (the blank columns) or date diet (the filled columns). Data are presented as the mean \pm SD $(n=5) . * p<0.05,{ }^{* * *} p<0.005$.
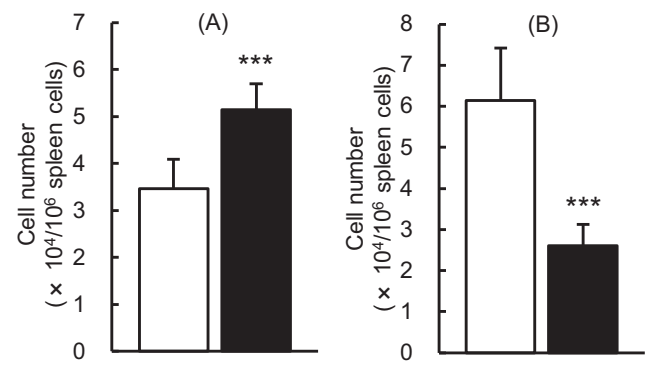

Fig. 4. The number of spleen IFN $-\gamma^{+} \mathrm{CD} 4^{+}$cells (A) and $\mathrm{IL}-4^{+} \mathrm{CD} 4^{+}$cells (B) in BALB/c mice given the control diet (the blank columns) or date diet (the filled columns). Data are presented as the mean \pm SD $(n=5)$. $* * * p<0.005$.

given the date diet and the mice given the control diet at the same weeks of age. Dunnett's multiple comparison tests for one-way ANOVA were used to analyze the numbers of immunocompetent cells cultured with polyphenols. All other analyses were assessed using Student's $t$-test. All analyses were performed using the two-sided test, and differences were considered significant when $p$-values were less than 0.05 .

\section{RESULTS}

\section{Effects of a date diet on allergic symptoms in mice}

Five-week-old $\mathrm{BALB} / \mathrm{c}$ mice were given a date diet or a control diet for $6 \mathrm{wk}$. No significant difference in body weight was observed between the mice given these diets (data not shown).

Figure 2 represents the number of sneezes (A) and nose rubbings (B) of the mice. The number of sneezes was significantly lower in mice between 9 and $11 \mathrm{wk}$ of age that were given the date diet than in mice given the control diet. The number of nose rubbings was significantly lower in mice between 8 and 11 wk of age that were given the date diet than in mice given the control diet.

Effects of a date diet on total and Df-specific IgE levels in mouse serum

Figure 3 shows the serum level of total (A) and Dfspecific (B) IgE. The total IgE level was significantly lower in mice given the date diet than in mice given the control diet. In addition, the Df-specific IgE level was significantly lower in mice given the date diet than in mice 

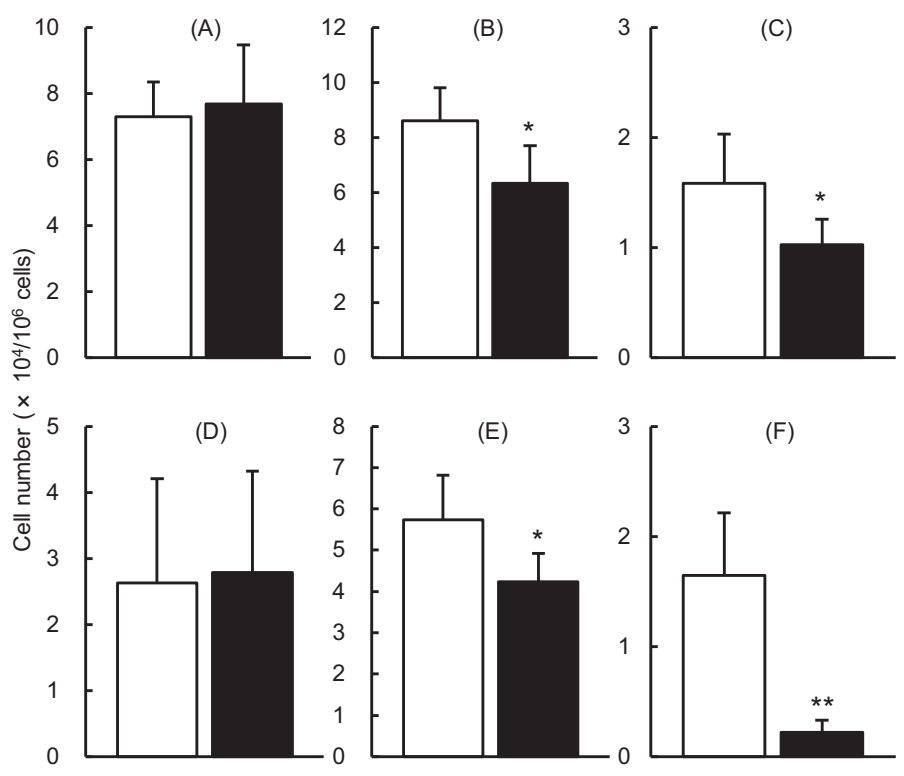

Fig. 5. The number of immunocompetent cells in the spleen and Peyer's patch of BALB/c mice given the control diet (the blank columns) or date diet (the filled columns). Spleen $\mathrm{CD} 80^{+} \mathrm{CD} 11 \mathrm{~b}^{+}$cells (A); spleen $\mathrm{IgE}^{+} \mathrm{B} 220^{+}$cells (B); spleen $\mathrm{Fc} \varepsilon \mathrm{RI} \alpha^{+} \mathrm{CD} 117^{+}$cells $(\mathrm{C})$; Peyer's patch $\mathrm{CD} 80^{+} \mathrm{CD} 11 \mathrm{~b}^{+}$cells (D); Peyer's patch $\operatorname{IgE}^{+} \mathrm{B} 220^{+}$cells (E); Peyer's patch Fc $\varepsilon \mathrm{RI}-$ $\alpha^{+} \mathrm{CD} 117^{+}$cells (F). Data are presented as the mean $\pm \mathrm{SD}(n=5) .{ }^{*} p<0.05,{ }^{* *} p<0.01$.

Table 1. Number of immunocompetent cells in spleen cells cultured with six polyphenols identified in the date extract.

\begin{tabular}{|c|c|c|c|c|c|c|c|}
\hline \multirow{3}{*}{$\begin{array}{l}\text { Immunocompetent } \\
\text { cell }\end{array}$} & \multicolumn{7}{|c|}{ Number of cells $\left(\times 10^{4} / 10^{6}\right.$ spleen cells $)$} \\
\hline & \multicolumn{7}{|c|}{ Polyphenol } \\
\hline & Free & $\begin{array}{c}\text { Protocatechuic } \\
\text { acid }\end{array}$ & $\begin{array}{l}\text { Chlorogenic } \\
\text { acid }\end{array}$ & Caffeic acid & Syringic acid & Pelargonin & Ferulic acid \\
\hline $\operatorname{IgE}^{+} \mathrm{B} 220^{+}$ & $8.70 \pm 0.73 a$ & $7.84 \pm 0.63 a$ & $6.67 \pm 0.55 b$ & $7.60 \pm 0.57 \mathrm{a}$ & $7.73 \pm 0.72 \mathrm{a}$ & $5.72 \pm 0.43 c$ & $6.89 \pm 0.31 b$ \\
\hline $\mathrm{Fc} \varepsilon \mathrm{RI} \alpha^{+} \mathrm{CD} 117^{+}$ & $1.51 \pm 0.20 \mathrm{a}$ & $1.18 \pm 0.11 \mathrm{a}$ & $0.81 \pm 0.16 b$ & $1.23 \pm 0.25 \mathrm{a}$ & $1.47 \pm 0.33 \mathrm{a}$ & $0.77 \pm 0.36 b$ & $1.29 \pm 0.14 \mathrm{a}$ \\
\hline
\end{tabular}

Spleens were obtained from $\mathrm{C} 3 \mathrm{H} / \mathrm{HeN}$ mice at $6 \mathrm{wk}$ of age bred with a commercially available diet.

Data are represented as the mean $\pm \mathrm{SD}(n=5)$.

Items indicated with different letters (i.e. a, b, c) are significantly different $(p<0.05)$.

given the control diet.

Effects of a date diet on the number of immunocompetent cells in the spleen and Peyer's patch of mice

Figure 4 represents the number of spleen IFN$\gamma^{+} \mathrm{CD}^{+}(\mathrm{A})$ and IL- $4^{+} \mathrm{CD} 4^{+}$(B) cells in 11-wk-old mice. The number of IFN- $\gamma^{+} \mathrm{CD} 4^{+}$cells was significantly higher, although the number of $\mathrm{IL}-4^{+} \mathrm{CD} 4^{+}$cells was significantly lower, in mice given the date diet than in mice given the control diet. The ratio of IFN $-\gamma^{+} \mathrm{CD}^{+}$ cells/IL- $4^{+} \mathrm{CD} 4^{+}$cells in the mice given the date diet was 1.97 , while that in the mice given the control diet was 0.56. Figure 5 shows the number of spleen and Peyer's patch $\mathrm{CD} 80^{+} \mathrm{CD} 11 \mathrm{~b}^{+}(\mathrm{A}, \mathrm{D}), \mathrm{IgE}^{+} \mathrm{B} 220^{+}(\mathrm{B}$, E) and $\mathrm{Fc} \varepsilon \mathrm{RI} \alpha^{+} \mathrm{CD} 117^{+}(\mathrm{C}, \mathrm{F})$ cells in 11-wk-old mice. The number of $\mathrm{IgE}^{+} \mathrm{B} 220^{+}$and $\mathrm{Fc} \varepsilon \mathrm{RI} \alpha^{+} \mathrm{CD} 117^{+}$cells was significantly lower in mice given the date diet than in mice given the control diet, although the number of $\mathrm{CD} 11 \mathrm{~b}^{+} \mathrm{CD} 80^{+}$cells did not differ significantly between these two mouse groups.
Effects of various date polyphenols on the number of immunocompetent cells in mouse spleen cell cultures

Table 1 shows the effect of six polyphenols previously identified in the date extract (7) on cell number of two different types of cultured immunocompetent cells from $\mathrm{C} 3 \mathrm{H} / \mathrm{HeN}$ mouse spleen. Chlorogenic acid, pelargonin and ferulic acid significantly decreased the number of $\mathrm{IgE}^{+} \mathrm{B} 22 \mathrm{O}^{+}$cells compared to polyphenol-free, protocatechuic acid, caffeic acid and syringic acid. Chlorogenic acid and pelargonin significantly reduced the number of Fc $\varepsilon \mathrm{RI} \alpha^{+} \mathrm{CD} 117^{+}$cells compared to polyphenol-free, protocatechuic acid, caffeic acid, syringic acid and ferulic acid.

\section{DISCUSSION}

Date fruit, or the fruit of the date palm tree, has been harvested in North Africa for at least 3,500 y (11), and its cultivation has now spread to the Middle East, parts of Central and South America, and Southern Europe $(12,13)$. Date fruit has been used in the Middle East 
as a folk medicine to prevent various infectious diseases, indicating its antimicrobial capacity $(14,15)$. We recently demonstrated that a date extract more strongly enhanced the cellular immune system than prune or fig fruit extracts (7). In addition, the ratio of spleen and Peyer's patch IFN- $\gamma^{+} \mathrm{CD} 4^{+} / \mathrm{IL}-4^{+} \mathrm{CD} 4^{+}$(Th1/Th2) cells was higher in $\mathrm{C} 3 \mathrm{H} / \mathrm{HeN}$ mice that were given the date extract-added diet than in mice given the extract-free diet.

Zhou et al. reported that type I allergic reactions were induced by intranasal administration of Df after intraperitoneal injection of Df in BALB/c mice (16). They also observed that the amount of total serum IgE in the mice without intraperitoneal immunization was approximately $0.2 \mu \mathrm{g} / \mathrm{mL}$, while that in mice with the immunization was approximately $4 \mu \mathrm{g} / \mathrm{mL}$ or more (16). Hence, in the present study, we treated BALB/c mice with Df according to the procedure described by Zhou et al. The serum total IgE amount in the $\mathrm{BALB} / \mathrm{c}$ mice given the control diet was 9.75 $2.87 \mu \mathrm{g} / \mathrm{mL}$ (Fig. 3). These facts indicate that allergic reactions could be induced in the mice appropriately.

The number of sneezing and nose rubbing events was significantly lower in mice given the date diet between the ages of 9 to 11 , and 8 to $11 \mathrm{wk}$, respectively, than in mice given the control diet (Fig. 2). Furthermore, the serum level of Df-specific IgE in the mice given the date diet was significantly lower than that in the mice given the control diet (Fig. 3). These results indicate that the feeding of mice with the date diet decreases allergic symptoms such as sneezing and nose rubbing via the suppression of Df-specific IgE production.

It is well established that IL-4, IL-5 and IL-13 produced by Th2 cells stimulate IgE production (1). The number of spleen Th2 cells in mice given the date diet was significantly lower than that in mice given the control diet (Fig. 4). This result indicates that the decrease in the serum level of Df-specific IgE in the mice given the date diet was due to a decrease in the number of Th2 cells.

It is known that $\operatorname{IgE}^{+} \mathrm{B} 220^{+}$cells are IgE-producing $B$ cells (plasma cells) (17). The number of spleen and Peyer's patch $\mathrm{IgE}^{+} \mathrm{B} 220^{+}$cells in mice given the date diet was significantly lower than that in mice given the control diet (Fig. 5B, E). These results indicate that the date extract may reduce the number of IgE-producing plasma cells in both the systemic and local immune systems.

The onset of type I allergic diseases is ultimately associated with the degranulation of mast cells. Expression of the FceRI, a high-affinity IgE receptor (1), on mast cells is necessary for degranulation. Mast cells are normally defined on the basis of cell surface expression of both FceRI $\alpha$ and CD117 (18). The number of spleen and Peyer's patch FceRI $\alpha^{+} \mathrm{CD} 117^{+}$cells in mice given the date diet was significantly lower than that in mice given the control diet (Fig. 5C, F). These results indicate that the anti-allergic effect of the date extract is also partly due to a reduction in the number of high-affinity IgE receptor-expressing mast cells.
We previously identified six kinds of polyphenols: protocatechuic acid, chlorogenic acid, caffeic acid, syringic acid, pelargonin and ferulic acid, in a date extract on UPLC (7). In that study, chlorogenic acid and caffeic acid increased the number of IFN- $\gamma^{+} \mathrm{CD} 4^{+}$cells; chlorogenic acid, pelargonin and ferulic acid enhanced the number of IFN- $\gamma^{+} \mathrm{CD} 49 \mathrm{~b}^{+}$cells; and chlorogenic acid, caffeic acid and ferulic acid increased the number of IL$12^{+} \mathrm{CD} 11 \mathrm{~b}^{+}$cells in $\mathrm{C} 3 \mathrm{H} / \mathrm{HeN}$ mouse Peyer's patch cell cultures. In the present study, we found that chlorogenic acid, pelargonin and ferulic acid significantly decreased the number of $\mathrm{IgE}^{+} \mathrm{B} 220^{+}$cells, whereas chlorogenic acid and pelargonin significantly reduced the number of $\mathrm{Fc} \varepsilon \mathrm{RI} \alpha^{+} \mathrm{CD} 117^{+}$cells (Table 1 ). These results suggest that chlorogenic acid, pelargonin and ferulic acid might be associable with the reduction of IgE-producing plasma cell and high-affinity IgE receptor-expressing mast cell numbers in the mice given the date diet. On the other hand, we also estimated that $\beta$-D-glucan could be present in the date extract (7). It has been reported that a certain structure of $\beta$-D-glucan suppressed allergic symptoms (19). It is therefore likely that the antiallergic effect of the date extract might be partly due to the action of $\beta$-D-glucan.

In conclusion, we note that date fruit appears to suppress acquired allergic responses via a reduction in the number of IgE-producing plasma cells and high-affinity IgE receptor-expressing mast cells. In order to use date fruit as an effective anti-allergic food material, a further investigation including the confirmation of the antiallergic effect of $\beta$-D-glucan in the date extract is now in progress.

\section{REFERENCES}

1) Platts-Mills TA. 2001. The role of immunoglobulin $\mathrm{E}$ in allergy and asthma. Am J Respir Crit Care Med 164: 1-5.

2) Shang XZ, Armstrong J, Yang GY, Volk A, Li J, Griswold DE, Emmell E, Li L. 2004. Regulation of antigen-specific versus by-stander IgE production after antigen sensitization. Cell Immunol 229: 106-116.

3) Pène J, Rousset F, Brière F, Chrétien I, Bonnefoy JY, Spits H, Yokota T, Arai N, Arai K, Banchereau J, De Vries JE. 1988. IgE production by normal human lymphocytes is induced by interleukin 4 and suppressed by interferons $\gamma$ and $\alpha$ and prostaglandin E2. Proc Natl Acad Sci USA 85: 6880-6884.

4) Pène J, Rousset F, Brière F, Chrétien I, Paliard X, Banchereau J, Spits H, De Vries JE. 1988. IgE production by normal human $\mathrm{B}$ cells induced by alloreactive $\mathrm{T}$ cell clones is mediated by IL-4 and suppressed by IFNgamma. J Immunol 141: 1218-1224.

5) Kim D, Kim SH, Park EJ, Kang CY, Cho SH, Kim S. 2009. Anti-allergic effects of PG102, a water-soluble extract prepared from Actinidia arguta, in a murine ovalbumininduced asthma model. Clin Exp Allergy 39: 280-289.

6) Lee M, Kim S, Kwon OK, Oh SR, Lee HK, Ahn K. 2009. Anti-inflammatory and anti-asthmatic effects of resveratrol, a polyphenolic stilbene, in a mouse model of allergic asthma. Int Immunopharmacol 9: 418-424.

7) Karasawa K, Uzuhashi Y, Hirota M, Otani H. 2011. A matured fruit extract of date palm tree (Phoenix dactylifera L.) stimulates the cellular immune system in mice. J 
Agric Food Chem 59: 11287-11293.

8) Al-Farsi M, Alasalvar C, Morris A, Baron M, Shahidi F. 2005. Comparison of antioxidant activity, anthocyanins, carotenoids, and phenolics of three native fresh and sun-dried date (Phoenix dactylifera L.) varieties grown in Oman. J Agric Food Chem 53: 7592-7599.

9) Tobita K, Yanaka H, Otani H. 2009. Heat-treated Lactobacillus crispatus KT strains reduce allergic symptoms in mice. J Agric Food Chem 57: 5586-5590.

10) Tobita K, Yanaka H, Otani H. 2010. Anti-allergic effects of Lactobacillus crispatus KT-11 strain on ovalbuminsensitized BALB/c mice. Anim Sci J 81: 699-705.

11) Copley MS, Rose PJ, Clampham A, Edwards DN, Horton MC, Evershed RP. 2001. Detection of palm fruit lipids in archaeological pottery from Oasr Ibrim, Egyptian Nubia. Proc Biol Sci 268: 593-597.

12) Rock W, Rosenblat M, Borochov-Neori H, Volkova N, Judeinstein S, Elias M, Aviram M. 2009. Effects of date (Phoenix dactylifera L., Medjool or Hallawi variety) consumption by healthy subjects on serum glucose and lipid levels and on serum oxidative status: a pilot study. J Agric Food Chem 57: 8010-8017.

13) Hong YJ, Tomas-Barberan FA, Kader AA, Mitchell AE. 2006. The flavonoid glycosides and procyanidin compo- sition of Deglet Noor dates (Phoenix dactylifera). J Agric Food Chem 54: 2405-2411.

14) Sallal A-KJ, Ashkenani A. 1989. Effect of date extract on growth and spore germination of Bacillus subtilis. Microbios 59: 203-210.

15) Shraideh ZA, Abu-Elteen KH, Sallal AK. 1998. Ultrastructural effects of date extract on Candida albicans. Mycopathologia 142: 119-123.

16) Zhou C, Kang XD, Chen Z. 2008. A synthetic Toll-like receptor 2 ligand decreases allergic immune responses in a mouse rhinitis model sensitized to mite allergen. J Zhejiang Univ Sci B 9: 279-285.

17) Manetz TS, Meade BJ. 1999. Development of a flow cytometry assay for the identification and differentiation of chemicals with the potential to elicit irritation, IgEmediated, or T cell-mediated hypersensitivity responses. Toxicol Sci 48: 206-217.

18) Brown MA, Sayed BA, Christy A. 2008. Mast cells and the adaptive immune response. J Clin Immunol 28: 671-676.

19) Yamada J, Hamuro J, Hatanaka H, Hamabata K, Kinoshita S. 2007. Alleviation of seasonal allergic symptoms with superfine beta-1,3-glucan: a randomized study. J Allergy Clin Immunol 119: 1119-1126. 